\title{
Yavaş Şehir Olgusunun Kentsel Yaşam Kalitesi Üzerindeki Algılanan Etkisi
}

The Influence of Slow City (Cittaslow) on the Perceived Urban Quality of Life

\author{
Yeşim COŞAR* \\ * Yrd. Doç. Dr., Fevziye Hepkon Sosyal Bilimler Meslek Yüksekokulu Dokuz Eylül Üniversitesi, P.K. 35460, Seferihisar - İzmir. \\ E-posta: yesim.cosar@deu.edu.tr
}

\section{MAKALE BILGILERI}

Makale işlem bilgileri:

Gönderilme tarihi: 9 Ağustos 2013

Birinci değerlendirme: 22 Ekim 2013

İkinci değerlendirme: 9 Aralı 2013

Kabul: 10 Aralık 2013

Anahtar sözcükler:

Yavaş şehir, Cittaslow,

Sürdürülebilir turizm,

Yaşam kalitesi, Yerel halk, Seferihisar.

\section{ARTICLE INFO}

Article history:

Submitted: 9 August 2013

Resubmitted: 22 October 2013

Resubmitted: 9 December 2013

Accepted: 10 December 2013

\section{Key words:}

Slow city, Cittaslow, Sustainable

tourism, Quality of life, Local people,

Seferihisar.

\section{ÖZ}

1990'lı yıllarda ortaya atılan ve son yıllarda Türkiye'de de kendisinden söz ettirmeye başlayan yavaş şehir ölçütleri incelediğinde, kentsel yaşam kalitesi ve sürdürülebilirlik olgusu ile örtüşen amaçları hedeflemekte olduğu görülmektedir. Bu çalışmanın temel amacı da sürdürülebilir turizm kapsamında yavaş şehir olgusunun kentsel yaşam kalitesi üzerindeki etkisini ortaya koymaktır. Çalışmada öncelikle yaşam kalitesinin anlamı ve içeriği hakkında bilgi verilmektedir. Sonrasında ise yavaş șehir olmanın sonuçlarının yerel halkın kentsel yaşam kalitesi algısı üzerine etkileri incelenmekte ve ilgili araştırma sonuçlarının tartışılması ile çalışma son bulmaktadır. Araştırma, 2012 yılı yaz aylarında İzmir ili Seferihisar ilçesinde bulunan yerel halk, işletme sahipleri ve belediye başkanı ile yürütülmüștür.

\section{Giriş}

Turizm, son yıllardaki önemli gelişmeler sonucunda, başlı başına bir araştırma konusu olmakla birlikte, endüstri anlamında diğer birçok sektör (inşaat, sağlık, mühendislik, ziraat vb.) ve araştırma alanı (tıp, eğitim, iktisat, sosyoloji, psikoloji vb.) ile doğrudan ya da dolaylı bir etkileşime sahiptir (Kozak, Kozak ve Kozak 2013). Diğer yandan ise turizm endüstrisinin oluşumunda ekonomik, doğal, siyasal ve kültürel unsurlar en önemli rolü üstlenmektedir (Fletcher, Fyall, Gilbert ve Wanhill 2013). Bu tür unsurlar, bir yandan turizm ürünü açısından temel çekicilikleri oluştururken, diğer taraftan da turizm endüstrisindeki gelişmeye bağlı olarak bir bölge üzerinde olumlu ya da olumsuz etkiye sahip olabilmektedir (Olalı ve Timur 1985; Çetin 2009). Kültürel unsurlar arasında yer alan yerel halk ise turistler ile etkileşimlerine bağlı olarak, turizm endüstrisi için ayrıca önemlidir. Yapılan araştırmalarda, yerel halkın turizm endüstrisi ile ilgili olarak farklı özelliklerde algılamalara sahip olduğu sonucuna ulaşılmıştır (bakınız Liu ve Var 1986; Doğan 1989; Ap 1992).

Bu kapsamda ele alınması gereken konulardan biri de yerel halkın yaşam kalitesi konusundaki algısının ölçülmesidir. Geçmiş yıllarda tamamlanan 
araştırma sonuçları, yavaş şehir olgusunun, özellikle o bölgede yaşam sürmekte olan yerel halkın kentsel yaşam kalitesi algısı üzerinde etkili olabileceği konusunda bazı ipuçları vermektedir (Uslu 2009; Doğutürk 2010; Ekşioğlu 2011). Yavaş şehir ölçütleri incelendiğinde, çevrenin önemli bir yer tuttuğunu, hatta ilk ana başlığı çevre politikalarının oluşturduğu görülmektedir. Bu bağlamda, hava, su ve toprak kalitesinin önemsenmesi, çevreye uyumlu yenilenebilir enerji kaynaklarının kullanımının teşvik edilmesi, evsel ve endüstriyel atıkların geri dönüşümünün desteklemesi ve yaygınlaşması, yavaş şehir olmanın öncelikleri arasında bulunmaktadır (Keskin 2010; Fullagar, Wilson ve Markwell 2012).

Sürdürülebilir şehir fikir ve uygulamalarının temelinde; dünya genelinde yaşanan sorunların çözümü için; şehir odaklı çözümün bulunması ve şehirlerin başka sistemler ile ilişkili bir sistem olduğu konusu yatmaktadır (Bramwell ve Sharman 2006). Yavaş şehir yaklaşımı da sürdürülebilir şehir yaklaşımından biri olarak tanımlanabilir. Sürdürülebilir şehir yaklaşımının temelinde, yaşam ortamı olarak şehirlerin daha yaşanabilir ve sağlıklı yerler olmasının sağlanması, yerel ölçekte atılan adımlar ile küresel ölçekte sürdürülebilirliğin sağlanması hedefi güdülmektedir (Knox 2005; Uslu 2009).

Benzer bir amaçla, 28 Kasım 2009 tarihinden itibaren Türkiye ile tanışan yavaş şehir olgusuna, ilk önce İzmir'e bağlı Seferihisar ilçesi sahip olmuştur. İlerleyen yıllarda, yavaş şehir hareketinin Türkiye'de yaygınlaşması için, 2010 yılında Akyaka (Muğla), Yenipazar (Aydın), Gökçeada (Çanakkale) ve Taraklı (Sakarya) kentleri, yavaş şehir olmak için çalışmalara başlamıştır. 24 Haziran 2011 tarihinde Polonya'da düzenlenen Yavaş Şehir Uluslararası Kongresi'nde ilan edilen kentlerle birlikte Türkiye'deki yavaş şehir sayısı beş olmuş ve Türkiye'de Yavaş Şehir Ulusal Ağı kurulmuştur (http://www.cittaslowturkiye.org/cittaslow-turkiye.html). 2013 yılı itibariyle Türkiye'de, Akyaka (Muğla), Gökçeada (Çanakkale), Halfeti (Şanliurfa), Perşembe (Ordu), Seferihisar (İzmir), Vize (Kırklareli), Yalvaç (Isparta), Yenipazar (Aydın) ve Taraklı (Sakarya) olmak üzere dokuz adet yavaş şehir bulunmaktadır.

Yavaş şehir sayısındaki bu tür bir artışla birlikte, konuyla ilgili Türkiye'de son yıllarda çeşitli içerikte yürütülen yayın sayısında da artış gözlenmektedir.
Örneğin; Yurtseven ve Kaya (2011), Seferihisar'da tamamlamış olduğu bir araştırmada, yavaş şehir çekiciliği ile ziyaretçi tipi arasında doğrusal bir ilişki kurmaktadır. Özdemir (2012), kırsal turizm kapsamında yavaş şehir olgusunun kırsal kalkınma üzerinde oynayabileceği önem üzerinde durmaktadır. Yavaş şehir olgusuna koruma ve planlama penceresinden yaklaşan yazarlara rastlamak da mümkündür (Bilgi 2013). Her ne kadar ampirik olarak desteklenmemiş olsa da yavaş şehir olgusu$\mathrm{nu}$, turizm kapsamında destinasyon markası yaratma açısından ele alan çalışmaların varlığ 1 da bilinmektedir (Karabağ, Yücel ve İnal 2012).

Son yıllarda çevresel sorunların artması, doğal çevrede oluşan tahribat ile yaşanabilir ve yaşayabilir alanlar oluşturulması adına kentlerde sürdürülebilirlik kavramı ile ilişkili bazı ölçütler ile yaşam kalitesinin arttırılması hedeflenmektedir (Bilgi 2013). Yavaş şehir ölçütlerine bakıldığında, kentsel yaşam kalitesi ve sürdürülebilirlik olgusu ile örtüşen amaçları hedeflemekte olduğu; ancak turizm yazınında bu anlamda yürütülen araştırmaların nitelik ve nicelik olarak yeterli olmadığı görülmektedir. Bu çalışmada da yavaş şehir olgusu ile yaşam kalitesi arasındaki ilişkiyi ortaya koymak amacıyla, öncelikle yaşam kalitesinin anlamı ve içeriği hakkında bilgi verilmekte; sonrasında ise yavaş şehir ve kentsel yaşam kalitesi algısı arasındaki ilişkiyi inceleyen araştırma sonuçlarına yer verilmektedir.

\section{KAVRAMSAL ÇERÇEVE}

Yaşam kalitesi kavramı, modern yaşamın gelişmesi ve toplumların çağdaşlaşması ile birlikte gündeme gelen ve gelişen bir kavramdır (Marans 2007). Yaşam kalitesi en geniş tanımıyla; gerek birey gerekse toplumsal açıdan yaşamın genel durumunu ifade etmektedir. Felsefe, sağlık, kentsel yaşam, sosyoloji vb. gibi birçok alan ile ilişkisinden dolayı, yaşam kalitesi farklı tanımlara sahiptir (Neal, Uysal ve Sirgy 2007; Sapancalı 2009).

Von Kamp ve arkadaşları (2003) yaşam kalitesini, çevrenin ölçülebilir mekânsal, fiziksel ve sosyal bileşenleri ve bu bileşenlerin algılanma biçimlerini bir arada ele alan ve buna göre, bireylerin algılamalarını sadece nesnel özellikleri ile değil, öznel özellikleri ile değerlendirdiği bir yaklaşımla ele almaktadırlar. Szalai (1980), yaşam kalitesini, bireyin varoluş hali, refahı ve yaşam doyumu ile iliş- 
kilendirmekte ve yaşam kalitesinin, objektif gerçek etmenler ile bireysel alg1 ve değerlendirmelere dayalı öznel etmenler ile şekillendiğini belirtmektedir (Marans 2007). Campbell'e göre (1976) yaşam kalitesi, yaşamın tamamından elde edilen deneyim sonucu ortaya çıkan ve bunun sonucunda kişinin yaşamında kendisini öznel olarak iyi hissetmesi hali olarak tanımlanmaktadır.

Veenhoven'a (2000) göre, kişinin yaşam kalitesi dört boyutlu bir yaklaşım ile ölçülebilir. Buna göre birinci olarak kişinin çevresinin yaşanabilirliği dikkate alınmaktadır. Kişinin doğal çevresi, konut, sağlık, güvenlik, ekonomik durum gibi yaşam kalitesi bileşenleri kişinin çevresinin yaşanabilirliğini ortaya koymaktadır. İkinci olarak, kişinin yaşam kabiliyeti dikkate alınmaktadır. Yaşam kabiliyeti, kişinin fiziksel ve ruhsal durumu, bilgi ve yetenekleri gibi özellikleri içermektedir. Üçüncü olarak, kişinin yaşam yararı, iyi bir vatandaş olma durumu, sağlıklı sosyal ilişkiler gibi özellikler dikkate alınmaktadır. Dördüncü ve son olarak ise kişinin yaşamının değerini bilmesi dikkate alınmaktadır. Dört noktanın tamamından kişi memnun ise kişinin yaşam kalitesi yüksektir sonucu çıkmaktadır. Bu dört noktanın bir tanesinde bile sorun olsa, kişinin yaşam kalitesini olumsuz etkilemektedir (Kabadayı 2006).

Yaşam kalitesi kavramının bugün bütün çă̆daş toplumların hedefi haline geldiği görülmektedir. 1960'lı yillardan sonra Amerika Birleşik Devletleri'nde ortaya çıkan yaşam kalitesi yaklaşımı, 1990'lı yıllardan sonra Avrupa Sosyal Modeli'nin tamamlayıcısı haline gelmiştir. Bugün Avrupa Birliği'nin sosyal politikaya ilişkin temel hedefi "yaşam koşullarının iyileştirilmesi ile birlikte Avrupa toplumunun yaşam kalitesini yükseltme" olarak tanımlanabilir. İnsanlar için kaliteli bir yaşam sürme modern dünyada bir hedef değil, herkes için bir hak, politikacılar ve yöneticiler için ise sağlanması zorunlu bir durumdur. Herkes için yaşam kalitesi hakkı, sağlık, eğitim, konut, güvenlik, çevre, toplumsal ve siyasal yaşama katılım ve güven içinde onurlu yaşamaya dair geniş bir anlam içermektedir. Yaşam kalitesine ilişkin bu hakların her biri önemlidir. Bu haklar, bir bütünlük içerisinde sağlanmalıdır. Bu hakların bir tanesinin dahi yetersiz olması durumunda, kişi ya da kişilerin yaşam kalitesi olumsuz etkilenmektedir (Sapancalı 2009).

\section{Kentsel Yaşam Kalitesi}

Dünyada hızla artan kentleşme ile birlikte insanların önemli bir bölümü kentlerde yaşamaya başlamıştır. Bu durum şehirlerdeki yaşam kalitesini küreselleşmenin güncel sorunlarından biri haline getirmektedir (Marans 2007). Benzer bir gelişme, son 50 yillık dönemde Türkiye'de de yaşanmaktadır. 2012 yılı verilerine göre Türkiye'de toplam nüfusun \%77,3 lük kısmı kentsel alanlarda (il ve ilçe merkezleri), geriye kalan kısmı ise kırsal alanlarda yaşamaktadır (TUIKK 2013). Yaşam kalitesi üzerine yapılan araştırma ve çalışmaların çokluğu ve hızla artan kentleşme olgusu, kent ve yaşam kalitesi kavramlarını bir araya getirmektedir. 1960'lı yıllardan bu yana yaşam koşulları olarak kullanılan birçok konuyu içeren yaşam kalitesi kavramı, 1990'11 yıllardan itibaren farklı alanlardaki bilim insanlarının üzerinde çalıştığı ve araştırma yaptığı bir kavram olmuştur. Kentsel yaşam kalitesi, kentlinin gereksinimi olan hizmetin ve tüm koşulların arz ve talebi arasındaki oran olarak açıklanabilir (Yıldız 2007).

Kentsel yaşam kalitesi dar anlamıyla, toplumsal, ekonomik ve mekânsal ögeler açısından kent tanımına giren yerlerde, kentsel altyapı, ulaşım, iletişim, konut, hava kirliliği, güvenlik, çevre temizliği gibi olanakların, çeşitli kuruluşlar tarafından önceden belirlenmiş standartları sağlaması ya da önceden belirlenen standartların üzerinde çıkması durumudur (Geray 1998). Geniş anlamıyla kentsel yaşam kalitesi ise toplumsal, kültürel ve siyasal süreci de içermektedir. Buna göre kentin, belirli hizmetleri belirli standartta sunmasından öte, sunulan hizmetlerden bütün kent sakinlerinin, eşit, dengeli gereksinmeleri oranında yararlanması sağlanmalıdır. Bunun yanı sıra, kent sakinlerinin kente ilişkin karar alma süreçlerine, kültürel ve toplumsal etkinliklere katılma olanaklarının da sağlanmış olması gerekmektedir (Geray 1998).

Kentsel yaşam kalitesi, hizmetin bütün kent sakinlerine, önceden belirlenmiş standartta sağlanmasının ötesinde kentli haklarında sakinlere sağlanmış olması ile ilgilidir. Temel insan hak ve özgürlükleri ile birlikte dayanışma hakları arasında sayılan çevre hakkı, kentli hakkı, çağdaş ve yaşanılabilir planlı bir çevre kentsel yaşam kalitesinin temel göstergeleri arasında sayılabilmektedir (Kabadayı 2006; Yıldız 2007).Kent yönetimi; bu alanlarda yapacağ 1 çalışmalarda, evrensel standart ile sakinlerin öznel durumunun ortaya çıardığı öncelikleri 
dikkate almalıdır (Koçak 2008). Son 25 yılda kentsel yaşam kalitesinin ölçülmesi konusunda ölçüt ve göstergelerin oluşturulması için önemli çalışmalar yapılmıştır. Yapılan çalışmalar sonucu ortaya fark1 göstergeler çıksa da bu göstergeler genel olarak; açık ve kapalı mekân standardı (çevre temizliği, yeşil alan, doğal çevre niteliği vb), vatandaşların refahı (gelir düzeyi, gelir dağılımı, satın alma gücü, işsizlik, güvenlik vb), hizmet çeşitliliği ve kalitesi (eğitim, sağlık, eğlence, ulaşım vb) konularını içermektedir (Yildız 2007).

\section{Yavaş Şehir - Yerel Halkın Yaşam Kalitesi}

Yavaş şehir kavramı, daha çok o şehirde yaşam süren yerel halkın, doğası ve kültürü bozulmamış bir ortamda, çevre kirliliğinden uzak bir şekilde günlük yaşamını belirli bir konfor içerisinde devam ettirmesini mümkün kılmak için günümüz modern şehir kavramına alternatif olarak ortaya atılmış bir kavramdır (Mayer ve Knox 2006). Günümüzün metropol şehirlerinde iş yaşantısının beraberinde getirdiği kısıtlı zaman, çıkılan ve gidilen mekan arasında harcanan ek bir dilim ile daha da kısalmakta, verilen sözlerin yerine getirilmesi insanlar üzerinde baskı yaratmakta, bir yerden başka bir yere ulaşım çevre ve gürültü kirliliği yaratmaktadır (Bilgi 2013). Bütün bunların sonucunda, stres gibi ortak bir paydada buluşan metropol insanları ortaya çıkmaktadır.

Diğer taraftan, sanayi üretiminin olmadığı ya da yoğun olmadığı, teknolojinin sadece temel gereksinimler için kullanıldığı, doğasını ve kültürel kimliğini korumayı başarabilmiş bir yerleşim düşünülebilir (Eceral ve Özmen 2009). Bu tür bir şehirde, yaşam koşuşturma içinde geçmemekte, büyük alışveriş merkezleri yerine küçük dükkân ya da mini marketlerden alışveriş yapılmakta ve hatta semt pazarından doğal ürünler rahatlıkla satın alınarak restoran ya da evlerde tüketilebilmektedir. Gürültü kirliliği, trafikte beklerken kaybedilen zaman sonucunda ortaya çıkan stres, şehir merkezinde ya da etrafında görselliği rahatsız eden bir yapılaşma gibi olumsuzluklara rastlamak mümkün olmayabilir. İşte bunlar, üretim yerine dünyanın kaynaklarını hızlı bir şekilde tüketime, koruma yerine kullanmayı teşvik eden metropol şehirlere alternatif olarak ortaya atılan yavaş şehirlerdir (Bilgi 2013).

Yavaş şehir tüzüğüne bakıldığında, yavaş şehir üyesi olan yerleşimlerde bulunması gereken ya da üyelerin taşımakla sorumlu oldukları şartların sürdürülebilirlik ile uyumlu olduğu görülecektir (Ergüven 2011). Yavaş şehir akımının önemsediği ilkeler; geri kazanım ve geri dönüşüm tekniklerine değer verilmesi, bölgenin dokusunun karakteristik özelliğinin korunması ve geliştirilmesine yönelik uygulanan bir çevre politikası; bölgede oturmak için değil ona değer verildiği için, onu bozmayan fonksiyonel olarak uygulanan bir altyapı politikası; çevrenin ve şehir dokusunun kalitesini arttırmaya yönelik teknoloji kullanımı, genetiği değiştirilmiş gıdalar yerine doğal teknikler ile elde edilen ve doğaya uyumlu gida maddelerinin üretim ve tüketiminin sağlanmasıdır (Mutdoğan 2010).

Metropol yaşamı ile yavaş şehir yaşamı aralarındaki bu temel farklılık, sürdürülebilirlik anlamında yerel halkın yaşam kalitesinin devamlılığını gösterecektir. Sahip olunan doğal, kültürel ve ekonomik kaynakları; sadece günümüz insanı ya da turistinin temel gereksinimi için söz konusu değildir (Mutdoğan 2010; Kozak 2013). Aksine, ilerleyen yıllarda da benzer bir yaşama sahip olmayı hayal eden gelecek kuşakların beklentilerini de karşılayacak şekilde yaşam standardının koruma altına alınmasını hedefleyen bir anlayış biçimi olan sürdürülebilirlik, son yıllarda dünyanın birçok ülkesinde doğal kaynakların kullanımı açısından ele alınmaktadır. Bu kaynakların yok olmasının, yerel halkın yaşam kalitesinin de yok olması anlamına geldiği de bilinmektedir (Bilgi 2013; Eceral ve Özmen 2009).

Turizm endüstrisinin doğrudan beslendiği doğal ve kültürel kaynaklar da kısıtlı düzeyde olup bunların turizm nedeniyle yok olması, sadece bugün için değil insanlar var olduğu sürece farklı zaman dilimlerinde turizm faaliyetlerine katılacak geleceğin turistleri ve yerel halkı için de bir endişe olacaktır. Belki de bu nedenle, yerel halk turizm endüstrisinin hızlı gelişmesi konusunda çoğu zaman olumsuz bir düşünceye sahip olabilmektedir. Şöyle $\mathrm{ki}$; turizm endüstrisindeki gelişme genellikle tüketici gereksinimlerini dikkate alırken, yerel halkın gereksinimlerini ya da geleceğe yönelik beklentilerini göz ardı etmekte; daha da önemlisi, gelecek yaşamları için kendi yaşamlarının devamında etkili olacak kaynakların birden yok olması ya da hasar görmesi sorunu ortaya çıkabilmektedir.

Son olarak, yavaş şehir-yaşam kalitesi arasında kendisini gösteren çelişkiye de yer vermek gerekmektedir. Her ne kadar yavaş şehir kavramı, baş- 
langıçta daha çok yerel halkın yaşam kalitesi için düşünülmüş olsa da ilerleyen yıllarda turizm aç1sından da bir çekicilik olarak tanıtılmaya başlanmıştır. Tatil sırasında turistler, kendilerini rahatsız edecek çevre kirliliğinden rahatsız olabilmekte ve doğal yerine yapay ürünleri tüketmek zorunda kalabilmektedirler. Turist, turizm için temel bir ürün olarak sunulan doğal kaynakların ve kültürel yaşamın bütün unsurlarının yok olmasına aracılık yapmakta, teknolojiden kaçarken kendisini bütün bu oluşumların ortasında bulabilmektedir. Sonuç olarak, tatile çıkmadan önce aradığ 1 rahat ve huzur dolu bir yaşam yerine, kargaşa ve stres dolu bir şekilde evine ya da işine dönmek zorunda kalabilmektedir. İşte bütün bu nedenlerle, yavaş şehir oluşumunun yeni bir kavram olarak turizm hareketlerinin sürekliliği ve sürdürülebilirliği için turizm arzı ve tatil sonrasında sağladığı yaşam kalitesi ile turizm talebi açısından önemli bir araç olma potansiyeline sahiptir. Ayrıca o bölgede yaşayan yerel halk da benzer şekilde kentleşme ya da turizm sonucu ortaya çıkan göç ve yapılaşma ile birlikte, beklemediği olumsuz bir yaşama sahip olabilmektedir. Böyle bir sonuç, yaşam kalitesinin geri getirilemez bir şekilde hasar görmesine neden olabilir. Yerel halk, iki tercih arasında kalabilmektedir: Ya bütün bu olumsuzluklara katlanılması ya da bir başka mekâna taşınma kararının alınması. Bu kararlardan hangisinin alınacağ 1 ise halkın sahip olduğu psikolojik, sosyal ve ekonomik şartlara bağlı olacaktır.

\section{ARAŞTIRMANIN YÖNTEMI}

Bu çalışma, Türkiye'de turizm alanında daha önce tamamlanmış bir benzerinin olmaması açısından önemlidir. Ayrıca, dünyada ve Türkiye'de yeni gelişmekte olan bir kavram olması nedeniyle daha yakından anlaşılması ve turizm endüstrisi ile ilişkisi bağlamında yerel halk ve turistler açısından sonuçların tartışılması da önem taşımaktadır. Yerinde gözlem, Seferihisar'ın Türkiye'nin yavaş şehir başkenti olması ve yazarın bu ilçede yerleşik olunması nedeniyle yılın farklı zamanlarında İzmir'in Seferihisar ilçesinde yapılmıştır. Gerçekleştirilen bu gözlem ile yazın taraması sonucunda görüşme soruları oluşturulmuştur. Soru listelerinin hazırlanması aşaması, alan yazın incelemesi sonucu ortaya konulan araştırmanın amacının, araştırma sorularına dönüştürülmesi ve bu konuda uzman kişilerin görüşlerinin alınması ile oluşturulmuştur. Görüşme tekniğinin olumsuzluklarını ortadan kaldırabilmek amacıyla, sorunun çözümüne yönelik derinlemesine bilgi sahibi olabilmek için yarı yapılandırılmış görüşme tekniğine uygun olarak soru listesi oluşturulmuş ve yapılan görüşmeler görüşme anında kalem-kâğıt ile not edilerek kayıt altına alınmıştır.

Nitel araştırmaların güvenirliliğinin sağlanmasında temel ölçütler arasında, araştırmanın kim, kaç kişi ve kaç soru ile ne zaman ve nerede gerçekleştirildiği gelmektedir (Whittemore, Chase, Susan ve Carol 2001). Bulguların farklı kaynaktan alınan veriler ile uyumuna bakılması bakımından araştırma üç grup üzerinde yürütülmüştür. Görüşmeler, 17 Ağustos - 06 Eylül 2012 tarihleri arasında Seferihisar'da yaşayan yerel halk arasından seçilen 22 kişi (10 soru); 17 Ağustos - 30 Ağustos 2012 tarihleri arasında ilçede ticaret yapan işletmeci ya da yöneticilerden seçilen 24 kişi (sekiz soru); son olarak, 24 Eylül 2012 tarihinde Belediye Başkanı ile yapılan görüşme (dokuz soru) ile tamamlanmıştır. Her bir grup için kullanılan soru listesi Tablo 1 üzerinde verilmektedir. Katılımclların kendi bulunduğu ortamda gerçekleştirilen veri toplama sürecinde her bir kişi için ortalama görüşme süresi, 15-60 dakika arasında değişmiştir. Görüşmelerde, görüşme yapılacak kişinin gönüllü olarak görüşmeye katılmak istemesi ve yavaş şehir kavramı ile ilgili az da olsa bilgi sahibi olması dikkate alınmıştır. Görüşülen kişilere daha çok konuşma fırsatı verilmesi ve görüşmelerin olduğu gibi kayıt altına alınması ile daha geçerli verinin elde edilmesine zemin hazırlanmiştır.

Araştırmanın güvenirliğine bir başka temeli oluşturacak olan veri analizinde izlenen süreç ise şu şekildedir: Görüşme sırasında yazar tarafından elle tutulan kayıtlar, her bir görüşmenin hemen ardından bilgisayar ortamına aktarılmıştır. Sonrasında bütün kayıt listesi dikkatli bir şekilde okunarak içerik hakkında bilgi sahibi olunmaya çalışılmıştır. İkinci tur okumada, her görüşme için belirli başlıklar altında kodlama yapılmış ve birbirine benzeyen çok sayıdaki bilgi kümesi benzer başlıklar altında toplanmaya çalışılmıştır. Kalan veri kümesi üzerinde üçüncü ve son bir tur okuma daha yapılarak gözden kaçan veri olup olmadığı kontrol edilmiştir. Sürecin son aşamasında yapılan son bir kontrol ile her başlık altındaki metnin birbirleriyle uyumu ya da benzeşimi konusunda emin olmaya çalışıl- 
Tablo 1. Soru Listesi

\begin{tabular}{|c|c|c|c|}
\hline Sorular & $\begin{array}{l}\text { Yerel } \\
\text { Halk }\end{array}$ & $\begin{array}{l}\text { İşletme } \\
\text { Sahipleri / } \\
\text { Yöneticileri }\end{array}$ & $\begin{array}{l}\text { Belediye } \\
\text { Başkanı }\end{array}$ \\
\hline 1. Seferihisar'ın yavaş şehir olduğu hakkında bilginiz var mı? & $x$ & $\mathrm{x}$ & \\
\hline 2. Yavaş şehir kavramının anlamını biliyor musunuz? & $\mathrm{x}$ & $\mathrm{X}$ & \\
\hline 3. Yavaş şehir olarak kabulünden sonra Seferihisar'da ne gibi değişiklik gözlemlediniz? & $\mathrm{x}$ & & \\
\hline 4. Yavaş şehir olma unvanının, size ne gibi fayda sağladığını düşünüyorsunuz? & $\mathrm{x}$ & & \\
\hline 5. Yavaş şehir olma unvanının sizin için ne gibi olumsuzluklar getirdiğini düşünüyorsunuz? & $\mathrm{x}$ & & \\
\hline 6. Yavaş şehir hakkında ilçe halkının düşüncesi nedir? & $\mathrm{x}$ & $\mathrm{X}$ & \\
\hline 7. Yavaş şehir unvanı, ilçede turizmin gelişmesinde nasıl bir etkide bulunabilir? & $\mathrm{x}$ & $\mathrm{x}$ & $\mathrm{x}$ \\
\hline 8. Yavaş şehir unvanına başvuru düşüncesi nasıl gelişti? & & & $\mathrm{x}$ \\
\hline 9. Yavaş şehir olma süreci hakkında bilgi verir misiniz? & & & $x$ \\
\hline 10. Yavaş şehir olunması, ilçedeki yaşam kalitesini nasıl etkilemiştir? & $x$ & $\mathrm{x}$ & $\mathrm{x}$ \\
\hline 11. Yavaş şehir fikrini ilļe halkı nasıl karşıladı? & & $x$ & \\
\hline $\begin{array}{l}\text { 12. Yavaş şehir unvanının sürekliliği konusundaki düşünceniz nedir? } \\
\text { (Şehrin gelişmesi, yeni yatırımlar, yönetim değişikliği vb) }\end{array}$ & & & $x$ \\
\hline 13. Mesleğiniz? & $x$ & $x$ & $x$ \\
\hline 14. Yaşınız? & $x$ & $x$ & $x$ \\
\hline 15. Kaç yıldır Seferihisar'da oturuyorsunuz? & $x$ & $\mathrm{x}$ & $x$ \\
\hline
\end{tabular}

mıştır. Yazım aşamasında ise betimsel veri (textual data) ile yazın arasındaki uyum dikkate alınarak gerekli yorumların yapılmasına özen gösterilmiş, hem dil hem de içerik açısından temsil yeteneği daha yüksek olan metinler, doğrudan alıntı (direct quatation) olarak metin içinde kullanılmıştır.

\section{BULGULARIN DEĞERLENDIRILMESi}

Üç farklı grup ile yapılan görüşmelerden her biri soru için elde edilen veri, aşağıdaki şekilde ele alınmakta ve sonrasında da yorumlanmaktadır.

\section{Yerel Halk ile Yapılan Görüşmelerin Değerlendirilmesi}

İlk olarak, meslek dağılımı açısından farklı grupların temsil edildiği yerel halk grubunda, yüksek öğrenim gerektiren mesleklerin yanı sıra esnaf, ev kadını, çiftçi ve el sanatları gibi meslek gruplarından kişiler de yer almaktadır. Bu grubun yaş aralığı, 27 ile 68 arasında değiştiği için daha çok, orta ve ileri yaş grupları temsil edilmektedir. Seferihisar'da ikamet süresi, bir yıl ile 61 yıl arasında değişmektedir. Turist grubunda olduğu gibi yerel halktan oluşan katılımcıların profili de heterojen bir yapıya sahiptir.
Yavaş Şehir Üyeliğinin Kabulünden Sonra Seferihisar'da Gözlemlenen Değişim

Yöre halkının, yavaş şehir üyeliğinin kabul edilmesinden sonra beraberinde getirdiği değişimi nasıl algıladıklarını üç şekilde ele almak mümkündür. Öncelikle olumlu yönüne bakmak gerekirse bunları ekonomik açıdan, tanıtım açısından ve kültürel açıdan ele almak mümkündür. Bunlar arasında el emeğinin değer kazanması, ev hanımlarının çalışmaya başlaması, yeni istihdam alanlarının yaratılması, organik üretimin ve pazarın teşvik edilmesi, müşteri olarak daha fazla insan gelmesi ve halkın gelirinin artması, yörede çekilen dizi-film sayısında artış olması, binaların dış görüntüsünün düzenlenmesi, halkın çevre temizliği bilincini kazanması ve düzenlenen sosyal ve kültürel faaliyet sayısında görülen artış gelmektedir.

Seferihisar'a dışarıdan gelen insan sayısı arttı, özellikle İstanbul'dan. Üretici pazarı ve kale içinde yöresel pazar kuruldu ve bu pazarlar çok ilgi görüyor. Özellikle bu pazarların kurulduğu günlerde, çevreden çok fazla ziyaretçi geliyor. İlçede tarım ürünlerinin değeri arttı ve bunların pazarlanması sağlandı (Katılımcı No: 5 - Ziraat Mühendisi).

Diğer yandan, yavaş şehir üyeliğinin elde edilmesiyle birlikte, beraberinde getirdiği olumsuz- 
lukların daha yoğun olduğunu dile getiren katılımcıların da sayısı yüksektir (toplam 11 kişi). Dile getirilen olumsuzluklar arasında; diğer şehirlerden göç eden nüfus ve gelen ziyaretçilerle birlikte yaşanan nüfus artışı ve kalabalığın beraberinde getirdiği gürültü ve trafik sorunu, yörenin değer kazanmaya başlamasıyla yapılaşmanın artması ve bunun beraberinde getirdiği arsa fiyatlarındaki artış, yaz dönemlerinde özellikle günübirlikçi sayısında gözlemlenen önemli artış, doğal yaşamın özelliğini kaybetmeye yüz tutması, tabela isimlerinde yabancı kelimelerin kullanımındaki artış ve yöre dişından gelen girişimci sayısındaki artış yer almaktadır. Aşağıda yer verilen iki alıntı, ortaya çıkan olumsuzlukları özetlemek bakımından yeterli olabilir:

\begin{abstract}
Seferihisar'da son yıllarda nüfus arttı, ama bunun kal1$\mathrm{c}$ bir nüfus olacağına inanmıyorum. Bir süre sonra bu insanlar geri dönecekler. Yapılan reklamların getirdiği bir hareketlilik oldu, günübirlik ziyaretçi ve turist say1sında artış yaşandı. Özellikle emekli kesim buraya daha çok geliyor. Yaz nüfusu, yaşayan nüfusu beşe katliyor. İnşaat endüstrisi hareketlendi, dışarıdan buraya inşaat yapmaya gelenler oldu. Seferihisar'ın çevresinin sit alanı olmasına rağmen inşaatlar yapılıyor, eski evler yıkı1ıyor. Yaz aylarında yemek yiyecek ve vakit geçirecek yer bulamıyoruz (Katılımcı No: 2 - Bankacı).

Seferihisar, yavaş şehir özelliklerine tam ters bir gelişme gösterdi. Önceden yavaş bir şehirdi, şimdi hızlı bir şehir oldu. Dışarıdan göç aldı, özellikle emekli insanlar Seferihisar'a yerleştiler. Yavaş şehir olduktan sonra inşaatlara sinırlama getirilecek korkusuyla bir an önce işimizi yapalım düşüncesiyle bir inşaat patlaması yaşandı. Seferihisar bakir, doğal halini koruyamadı. Yerli ve yabancı ziyaretçilerin akınına uğradı (Katılımoı No: 21 - Esnaf).
\end{abstract}

Görüldüğü gibi Seferihisar'da yaşayan yöre halk1, yavaş şehir üyeliğinin elde edilmesi ve bunun daha çok bir tanıtım aracı olarak kullanılması nedeniyle, son yıllarda ortaya çıkan gelişmelerden memnun görünmemektedir. Çünkü yukarıda s1ralanan olumsuzluklar, gürültü, yaşam pahalı11ğı, günlük işleyişin bozulması, kendilerine sunulan hizmetlerde yaşanan sorunlar gibi nedenlerle sonuçta kendi günlük yaşam kalite düzeylerinin olumsuz anlamda gelişme gösterdiğini, aslında yavaş şehir olgusunun içeriği gereği, bu yöndeki beklentilerinin olumlu yönde olması gerektiğinin altını çizmektedirler. Üçüncü grupta yer alan etki ise bu yöndeki algılaması ne olumlu ne de olumsuz olan kesimi oluşturmaktadır. Görüşülen kişilerin birisinin 48 yaşında, emekli olduğu ve son yedi yıldır Seferihisar'da ikamet ettiği, bir diğerinin de
45 yaşlarında olduğu, tıp mesleğinden geldiği ve son bir yıldır yörede ikamet ettiği göz önüne alındığında, iki kişiden oluşan bu grubun gözlemleri hakkında fazla ipucu veremedikleri söylenebilir. Birinci kişi, ek olarak sadece yöresel pazarların öneminden; ikinci kişi de sadece, yavaş şehrin simgesi olan şehir merkezindeki salyangoz anıtından bahsetmiştir.

\section{Yavaş Şehir Olgusunun Yerel Halka Sağladığı Fayda}

Yavaş şehir olmanın Seferihisar'da yaşamakta olan yöre halkı üzerinde yarattığ 1 etkiyi olumlu ve olumsuz anlamda iki şekilde ele almak mümkündür. Öncelikle olumlu tarafından bakılacak olursa, yukarıda üçüncü başlıkta belirtilen değişim ile paralellik gösterdiği söylenebilir. Şöyle ki, bu konuda yöre halkı daha çok, elde edilen ekonomik ve kültürel fayda üzerinde durmuşlardır. Ekonomik fayda anlamında, yapılan başarılı tanıtım çalışmaları sonucunda elde edilen marka şehir olma ve bu sayede artan ziyaretçi talebi, beraberinde yöresel pazarlar gibi yeni düşünceleri uygulamaya geçirmiştir. Yöresel pazarların kurulmasıyla birlikte istihdam olanakları artmış, ev hanımlarına dönük yeni iş sahaları çıkmış, üreticiler 'daha ne üretebilirim' diye düşünmeye başlamışlardır. Böylelikle yöre ekonomisi canlanmaya ve elde edilen gelir artmaya başlamıştır. Bu konuda aşağıda iki alıntı bulunmaktadır:

Yavaş şehir olduktan sonra Seferihisar tanındı, ekonomik anlamda gelişme yaşandi. Ürettiklerimizi pazarlama şansına sahip olduk. Üretici ve tüketici aracısız birbirine ulaşabiliyor. Turistlere yöresel zenginliklerimizi tanıtma fırsatı yakaladık. Özellikle yöresel yemeklerimiz ön plana çıktı (Katılımoı No: 4 - Memur).

Seferihisar daha önce sadece deprem felaketiyle anılan bir şehir iken yavaş şehir ile birlikte çok reklamı yapıldı ve medyatik bir ilçenin yerlisi oldum. Gittiğim her yerde yaşadığım şehir tanınıyor ve insanlar yavaş şehir ile ilgili sorular soruyor (Katılımcı No: 13 - Ziraat Mühendisi).

Kültürel anlamda ise daha önceden kendi içine kapalı bir toplum olduğu dile getirilen Seferihisar halkı, sonrasında dişarıya açılma ihtiyacı duymuştur. Bunun üzerinde, eğitim düzeyi daha yüksek kimselerin göç ederek ilçede yaşamaya başlamaları, gelen ziyaretçi sayısında nitel ve nicel artış ve yılda bir kez ücretsiz düzenlenmeye başlanan sinema günlerinin etkili olabileceği söylenebilir. Ekonomik ve kültürel bakımlardan elde edilen faydanın, sonuçta ilçenin yaşanabilir ya da tatil yapıla- 
bilir marka şehir haline gelmesine ve yöredeki ev ve arsa fiyatlarının artmasına yol açtığı görülmektedir. Bu durum ise yöre halkı tarafından olumlu bir gelişme olarak değerlendirilmektedir.

Memur olduğum için bana ekonomik anlamda bir faydası olmadı. Ailem ürettiklerini pazarda satmaya başladi, onlara ekonomik olarak katkı sağladı. Her yıl sinema günleri düzenlenmeye başlandı, hiçbir ücret ödemeden bu filmleri izleyebiliyoruz. İnsanların bakış açısında olumlu değişmeler yaşandı. Ekonomik gelişmeler yaşand1. Herkes ne üretebilirim diye düşünmeye başladı (Katılımor No: 10 - Öğretmen).

Yukarıdaki alıntıdan da görüleceği üzere, yöre halkının elde ettiği fayda daha çok ekonomik açıdan ele alınmaktadır. Genel olarak bakıldığında, yavaş şehir markasının yöre halkı üzerinde genelde ekonomik ve kültürel anlamda faydası olduğunu dile getiren katılımcıların oranı oldukça yüksek çıkmaktadır. Bununla birlikte iki katılımcı, elde edilen faydadan öte, ortaya çıkan zararın daha fazla olduğunu düşünmektedir. Bu iki katılımcının vurgulamak istediği olumsuz durum, yaşanan gürültü kirliliğidir. Plajda yüksek sesli çalınan müzik, artan trafik ve düzenlenen ücretsiz halk konserlerinin ortaya çıkardığı gürültü burada etkili olmaktadir.

\section{Yavaş Şehir Olgusunun Yerel Halk Açısından Getirdiği Olumsuzluk}

Toplam sekiz katılımcı, yavaş şehir ölçütlerinin uygulanmaya başlaması ile birlikte kendileri açısından herhangi bir olumsuzluk yaşamadıklarını söylemektedir. Bir kısım katılımcı ise yaşanan olumsuzları daha çok şehrin geneli açısından ele alırken, diğer bir kesim de yaşanan olumsuzlukları kendi açılarından şu şekilde özetlemişlerdir: Bu kesim öncelikle, Seferihisar'in yavaş şehir için uygun bir kent olmadığını dile getirmektedir. Sonrasında ise artan göç ve ziyaretçi sayısı ile birlikte artan fiyat düzeyinden, geçmişte deneyim sahibi oldukları kültürel değerlerin günümüzde kaybolmakta olmasından, özellikle hafta sonları otopark sorunu yaşamalarından, geçmişte sahip olunan rahat şehir yaşamının yerini günümüzde sıkışık bir dokunun almasından ve insanlar arasındaki güven bunalımindan söz edilmektedir.

Buraya [Seferihisar'a] sakin olduğu için yerleştik, şimdi çok kalabalık. Ben eski Sığacık'ı istiyorum (Katılımo No: 20 - Emekli Öğretmen).

Kalabalık arttığı için yaşamımız zorlaştı. Özellikle hafta sonları trafik yoğunluğu rahatsız edici. Seferihisar'daki mevcut durum bu kalabalığı kaldıramıyor. Bunun d1şında bir olumsuzluk getirmedi (Katılımoı No: 18 - Bankacı).

Bu grup içinde yer alan bazı kimseler ise bu tür olumsuzlukların yavaş şehir olgusuna bağlanmasının doğru olmayacağını, diğer şekilde de günümüz şartları gereği, benzer bir değişimin ortaya çıkacağını vurgulamaktadırlar:

Seferihisar, yavaş şehir unvanı ile birlikte betonlaşmaya başladı, inşaat ve trafik yoğunluğu arttı, otopark sorunu başladı. İnsanlar için yürüyüş alanları azaldı. Gürültü ve hava kirliliği oluşmaya başladı. Ev kiraları arttı. Çocuklarımız daha kalabalık sınıflarda ders yapmak zorunda kalıyor. Eskiden Hidrellez zamanı tekneler ile giderek yemek yediğimiz bir yer vardı. Yöre halkının bir geleneğiydi, marinanın yapılmasıyla bu geleneğimiz yok oldu (Katılıme No: 4 - Memur).

Yukarıdaki alıntıdan da görüleceği üzere, ortaya çıkan kalabalık ya da kültürel bozulmanın nedeni her zaman, yavaş şehrin bir sonucu olmazken, yerel yönetimlerin kontrolündeki önceki yıllara ait başka bir planlama faaliyeti sonucunda da ortaya çıkabilmektedir.

\section{Yavaş Şehir Hakkında Yerel Halkın Düşüncesi}

Katılımcılara, Seferihisar'da yaşayan yöre halkının yavaş şehir olgusuna bakışları sorulduğunda ortaya çok farklı sonuçlar çıkmaktadır. Birincisi, yöre halkının yavaş şehrin ne anlama geldiği konusunda ayrıntılı bilgiye sahip olmadığı, bunun sadece bir isim değişikliği olarak algılandığ 1 ya da sadece Sı̆̆acık Mahallesi'nin yavaş şehir olarak düşünülmesidir. İkincisi, yapılan tanıtım çalışmaları ile birlikte yörede turizm hareketlerinin arttığını ve ekonominin canlandığını; sonuçta da yörenin ekonomik anlamda değer kazanmasından halkın son derece memnun olduğudur. Bu nedenle, yavaş şehrin sürdürülebilirliğinin sağlanması gerektiğini dile getirmektedirler.

Halk ekonomik gelişmeden memnun. Özellikle bayanlar evlerinde ürettiklerini satmaya başladılar ve ekonomik özgürlük kazandılar. Kale içinde yaşayanlar bu işi kira, vergi vb. gideri olmadan evlerinin önünde yapıyor. Yeni oteller yapılması ile halk için yeni istihdam alanları oluştu. Günübirlik ziyaretçiler sayesinde esnafın geliri arttı. Tekne turları ve ev pansiyonculuğunda da artış oldu (Katılımoı No: 4 - Memur).

Halk, yerel pazarın kurulmasından memnun. Seferihisar'ın merkezinde yaşayanlar biraz memnuniyetsiz, çünkü tüm gelişmelerin Sığacık Mahallesi'nde olduğunu düşünüyorlar. Bu nedenle, Sığacık Mahallesi yavaş şehir olmaktan daha çok memnun, onlara ekonomik anlamda katkısı çok daha fazla oluyor (Katılımoı No: 22 - Satış Elemanı). 
Üçüncü olarak, yöre halkının bu tür bir uygulamanın beraberinde getirdiği yaptırımlardan duyduğu rahatsızlık dile getirilmektedir. Örneğin; barlarda müzik sesinin yüksek düzeyde açlamaması, halkın "gelişmede yavaşlıyoruz ya da geri kalıyoruz" gibi endişelere kapılmaya başlaması gibi. Aşağıdaki alıntı ise daha çok, Seferihisar'ın geleceği konusunda yöre halkının duyduğu endişeye işaret etmektedir:

\begin{abstract}
... İlçe halkı Seferihisar'ın yavaş şehir mantığına ters bir şekilde geliştiğini düşünüyor. Yavaş şehir ilk dile geldiği zaman herkes çok olumlu bakıyordu. İnsanlar Seferihisar, Bodrum ya da Kuşadası gibi olmasın diyordu. Şu anda birçok kişi kalabalık ve trafikten şikâyetçi (Katılımcı No: 3 - Öğretmen).
\end{abstract}

Bütün bu örnekler, aslında yavaş şehir olgusunun içeriği ile doğrudan örtüşmektedir. Bilindiği gibi yavaş şehir, yerel halkın ve ziyaretçilerin yaşam kalitesi açısından, kontrol altında bir gelişmeyi ve yaşam biçimini savunmaktadır.

\section{Yavaş Şehir Olgusunun, Seferihisar Turizm Endüstrisinin Gelişmesindeki Etkisi}

Yavaş şehir olgusu ile birlikte, Seferihisar'da turizm endüstrisinin gelişimi konusunda iki farklı görüş ortaya çıkmaktadır. Birinci grup, Türkiye'de ilk yavaş şehir olmanın verdiği imaj avantajı ve yörede uygulamaya konulan ev pansiyonculuğu, yöresel ürünlerin ön plana çıkarılması ve halkın daha da bilinçlendirilmesi ile birlikte, ilçedeki turizm endüstrisinin gelecek yıllarda olumlu bir seyre sahip olacağı üzerinde dururken, beraberinde bazı öneriler de getirmektedirler:

İlçede [Seferihisar'da] turizm gelişmeye devam eder. Turistler, Seferihisar'ın yöresel özelliklerini ve yemeklerini görmek için geliyorlar. Bu özellikler korunduğu sürece turist çekmeye devam edecektir (Katılımoı No: 6 - Çiftçi).

Seferihisar, yavaş şehir ölçütlerine uygun bir şekilde gelişir ise az ama daha kaliteli turisti çekecektir. Bu durum, Seferihisar'a hem kültürel hem de ekonomik anlamda daha fazla katkı sağlayacaktır (Katılımo No: 3 Öğretmen).

Yerel yönetimler yavaş şehir özelliklerine sahip çıkarsa Seferihisar'da yavaş şehir özellikleri korunarak turizm gelişir. İşletmeler ve halk, yöresel özellikleri korumaya teşvik edilmeli (Katılımoı No: 19 - Emekli Bankacı).

Diğer bir grup ise yavaş şehir olgusu ile Seferihisar'da turizm endüstrisinin gelecekteki durumu arasında olumlu bir ilişkiden söz etme- mektedir. Artan ziyaretçi sayısı ile birlikte turizm endüstrisinin canlanmaya başlaması, gelecek için iyimser bir gelişme olarak görülmemektedir. Turizm endüstrisinin daha da gelişmesi ile birlikte, yörenin özelliğini kaybederek yavaş şehir olma bağlamında bir çekiciliğinin kalmayacağı ve sonuçta, Türkiye'nin Özzdere, Çeşme ve Kuşadası gibi diğer bazı turizm yörelerinde olduğu gibi hem hizmet hem de yaşam kalitesinde düşüşün olabileceği beklentisi egemendir.

\section{İşletme Sahipleri ve Yöneticiler ile Yapılan Görüşmele- rin Değerlendirilmesi}

Görüşme yapılan üçüncü grup, Seferihisar bölgesinde faaliyet göstermekte olan çeşitli işletmelerin sahipleri ya da yöneticileri ile yapılan birebir görüşmeden oluşmaktadır. Meslek dağılımı açısından, otel işletmelerinden hediyelik eşyaya, gıda satışından el sanatlarına kadar farklı bir yelpaze görülmektedir. Bu gruptaki katılımcıların yaş aralığ 19 ile 57 arasında değişmekle birlikte, genel ağırlık orta yaş lehinedir. Seferihisar yöresinde çalışma süresi de 1 ile 25 yıl arasında değişmekle birlikte, çoğunluk birkaç yıllık çalışma süresi ile sınırlıdır. Bunun nedeni olarak da Sığacık Mahallesi'nde birkaç yıl önce faaliyete geçen yat limanı çevresinde son dönemlerde açılan işletme sayısındaki artış gösterilmektedir.

\section{Yöre Halkının Yavaş Şehir Hakkında Düşünceleri}

Bu konuda üç farklı görüş ortaya çıkmaktadır. Birinci görüşü savunanlara göre, beraberinde getirdiği özellikle ekonomik kazanç fırsatları nedeniyle yavaş şehir, Seferihisar yöre halkı arasında memnuniyet ile karşılanmaktadır. Yöre halkının başlangıçta bu olgunun ne anlama geldiğini fazla anlayamadığı, ancak ileriki dönemlerde uygulamaya geçilmesiyle birlikte özellikle küçük üreticiler ve işletmeler için önemli olduğu görülmüştür. Salı günleri kurulan üretici pazarının yanı sıra kadınların kendi ürettiklerini satabildikleri diğer pazarların kurulması ve bunların yörenin tanıtımı ve pazarlanması konusunda önemli bir çekicilik haline gelmesinde, yavaş şehir olgusunun etkili olduğunu görmek mümkündür. Bunların yanı sıra bazı küçük ölçekli konaklama tesislerinin açılmaya başlanması, esnafın para kazanması ve mülk fiyatının artması nedeniyle olumlu bir bakışın ortaya çıktığı 
görülmektedir:

\begin{abstract}
Halk memnun, köy pazarı kuruldu ve halk için bir gelir kaynağı oldu. İnsanlar bahçesinde ürettiklerini, evde yaptığı yemekleri, el işlerini pazarda satabiliyorlar. Şehre gelen insan sayısında artış yaşand. Günübirlikçi ziyaretçiler esnafı memnun etti, kazançları arttı (Katılımcı No: 5 - Otel İşletmecisi).

Yavaş şehir olduktan sonra gelir düzeyi arttı. Kadınlar, evlerinin önünde ürettiklerini satmaya başladılar. Halk bu durumdan memnun. Yavaş şehir olmadan önce kış aylarında çok boştu, şimdi kış aylarında da pazar günleri hareketli, esnaf haftada bir günde olsa satış yapabiliyor (Katılımo No: 24 - Firın Sahibi).
\end{abstract}

Yine bu grubun temsilcileri, yavaş şehrin ortaya çıkardığı sonuçların yöre halkı tarafından sadece ekonomik açıdan değerlendirilmesinden rahatsız olduklarının, ancak bu modelin ölçütlerinin uygulanmasının ya da gelecek yıllarda sürdürülebilirliğinin ne şekilde sağlanması gerektiği konusuna gereken önemi vermediklerinin altını çizmektedirler. Böyle bir durum ise turizm endüstrisinde görmeye alışık olduğumuz, kontrolsüz gelişme sonucu ortaya çıkan aşırı ticarileşme ve yapılaşma sonucunda yörenin turizm açısından çekiciliğini kaybedebileceği tehlikesiyle karşı karşıya kalabileceğine işaret edebilir.

Halk sadece olaya ekonomik olarak bakıyor. Doğayı ve geleneklerini korumaya yönelik bir çabaları yok. Halk elindeki değerlerin farkında değil (Katılımcı No: $21-D a-$ lış Kulübü İ̧letmecisi).

İkinci grupta yer alanlar, Seferihisar'ın zamanla çekici hale gelmeye başlamasıyla birlikte ortaya çıkan olumsuz gelişmelerden yöre halkının rahatsızlık duymaya başladığını söylemektedirler. Rahatsızlık duyulan bu olumsuz gelişmeler arasında, aşırı ziyaretçi sayısının artışı ile birlikte ortaya çıkan kalabalık ve gürültü kirliliği yer almaktadır. Yine bu gruba göre, yat limanı çevresinde faaliyet gösteren bazı Sığacık esnafının yavaş şehrin ortaya çıkardığı sonuçlardan kendi açılarından memnun olmadıklarının düşünülmesi de diğer bir olumsuz gelişmedir. Bunun nedeni ise o çevrede hareketliliğin azalacağı beklentisi ile ekonomik anlamda gelir kaybına uğrayacakları gibi bir endişeye sahip olmalarıdır:

İlçe [Seferihisar] halkının bir kısmı yavaş şehir olmaktan memnun, bir kısmı ise memnun değil. Yavaş şehir olmak kazandırdı diyen de kaybettirdi diyen de var. Pazarcılar, esnaflar, balıkçılar genel olarak memnun. Kaleiçi pazarının kurulması ev kadınlarına gelir sağladı.
Genellikle bu bölgede yazlığı olanlar bölgenin tanınmasından ve kalabalıklaşmasından şikâyetçi. Gürültünün arttığını söylüyorlar ve doğal yapının bozulmasını istemiyorlar (Katılımoı No: 1 - Otel İşletmecisi).

İlçe [Seferihisar] gençleri yavaş şehir olmaktan memnun değil, müzik sesi kısılıyor, barlarda eğlenemiyorlar. Yaşlılar da burada kalabalığın artmasından şikâyetçi. Tatil amaçlı gelenler Bodrum, Çeşme vb. yerlerden daha sakin olduğu için memnun (Katılımeı No: 25 - Otel İşletmecisi).

Üçüncü grubun düşüncesi ise aşağıdaki ilk alıntıda da kısmen vurgulandığı gibi yöre halkının yavaş şehir konusuyla fazla ilgilenmediği ya da

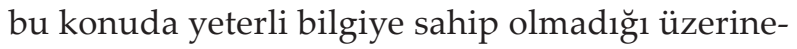
dir. Bu konuda, yöre halkının başlangıçta olumsuz düşündügünü, ancak olumlu yönlerini görmeye başladıktan sonra memnun olmaya başladığını da söylemek mümkündür.

Yavaş şehir konusunun, halkın pek fazla umurunda olduğunu düşünmüyorum. Yavaş şehir unvanı ile birlikte burası pazarlanmaya başladı. Hafta içi ölü bir şehir, hafta sonları ise normal dışı bir yoğunluk oluyor (Katılımo No: 2 - Otel İşletmecisi).

Halk, durumdan memnun; yine de bazı şikâyeti oluyor. Başlangiçta, özellikle erkekler çok tepki gösterdi, çünkü Sığacık Kaleiçi pazar yerinin kurulmasıyla eşleri çalışmaya başladı. Pazar günleri gürültü ve kalabalık arttı. Ekonomik getirisini gördükten sonra memnun olmaya başladılar (Katılımoı No: 4 - Kafe-bar İşletmecisi).

Yerel halkın yavaş şehir konusunda, başlangıçta olumlu bir tutum beslemez ve fazla ilgi göstermezken ilerleyen dönemlerde sağlanan ekonomik fayda ile birlikte tutum değiştirmeye başladığı görülmektedir. Örneğin; bazı erkeklerin, eşlerinin çalışmaya başlamaları ile birlikte, başlangıçta rahatsizlık duyarken, ekonomik anlamda faydasını görmeye başlamalarıla birlikte, fikir değiştirdikleri görülmektedir. Benzer durum, kalabalık ve gürültüden başlangıçta rahatsızlık duyan yöre halkı için de geçerlidir.

\section{Yöre Turizminin Gelişiminde Yavaş Şehir Olgusunun Algılanan Etkisi}

Seferihisar'da faaliyet gösteren işletmelerin sahip ya da yöneticileri, yavaş şehir olgusunun yöredeki turizm endüstrisinin gelişiminde olumlu yönde etkide bulunduğunun altını çizmektedirler. Bu gruba göre yavaş şehir, Seferihisar için önemli bir tanıtım kaynağı olmuş ve sonuçta insanlarda ortaya çıkan merak dürtüsü nedeniyle yöreye gelen ziyaretçi sayısında önemli bir artış ortaya çıkmıştır. Ye- 
ni otel işletmelerinin yapılması ile birlikte, özellikle yurtdışından yabancı turist gelmeye başladığı söylenmektedir. Seferihisar'ın yavaş şehir bakımından avantajlı olduğu ve kurallarının uygulanmaya devam edilmesi ile birlikte gelecekte daha çok turistin geleceği ve bunların otel dışına çıkmalarıyla yöre esnafının daha çok gelir elde edebileceğine vurgu yapilmaktadır.

Yavaş şehir olmasından çok, ev pansiyonculuğunun gelişmesi turizmi olumlu etkiler. Yavaş şehir olması daha çok günübirlik gelmesinde etkili çünkü çok fazla gezilip görülecek yeri yok, küçük bir yer. Yabancı turistlere yönelik büyük otellerin yapılması burada hareketliliği arttıracaktır (Katılımoı No: 15 - İşletmeci).

Sakin şehir olmak, turistlerin tatil seçimlerinde önceliği olacaktır. Slowfood bunu destekliyor. İnsanlar kalabalık şehirlerden sakin yerlere kaçmak istiyorlar. Elektrik kabloları yer altında olduğu, organik yiyeceklerin tüketildiği, bisiklet ile ulaşımın kolay olduğu bu şehri tercih edeceklerdir. Özellikle Seferihisar, kış aylarında daha sakin ve huzurlu bir şehir (Katılımcı No: 23 - Hediyelik Eşya Satıcısı).

Seferihisar'ın yavaş şehir olma şartlarını yeterince yerine getirmediği ve bu nedenle bazı doğal çevre üzerinde bazı sorunların ortaya çıktığı görülmektedir. Bir yandan yavaş şehir konusu gündeme getirilirken diğer taraftan yapılaşmanın, gürültü kirliliğinin ve büyük ölçekli otel inşaat sayısının artması bir çelişki olarak görülmektedir. Bu kesim, turizm endüstrisi ile ilgili olarak gelecek dönemlerde olumlu bir gelişme beklememekte; bunun nedenleri arasında ise yörenin turizm hareketliliği bakımından doyum noktasına yaklaşmasının önemli bir risk oluşturması gösterilmektedir.

\footnotetext{
Seferihisar'ın yavaş şehir olması, turizmin gelişmesini olumlu yönde etkiledi. Hiçbir şeyi olmayan bir ilçeden yavaş şehir unvanı ile birlikte değeri olan bir ilçeye dönüştü. İlçede turizm gelişmeye devam eder, kalabalıklaşır ve burası yavaş şehir olmaktan çıkabilir (Katılımoı No: 6 - Turizm İşletmecisi).

Seferihisar ve Sığacık, gelişmekte olan bir yer. Kimileri buranın Çeşme gibi kalabalık ekonomik kazancı çok olan bir yer olmasını istiyor. Biz buranın doğal özelliklerini koruyan, daha kaliteli turistlerin geldiği bir yer olmasını istiyoruz. Burası gelişmeye devam eder ama bu gelişme hangi yönde olur bunu bilemiyorum (Katılımcı No: 25 - Otel İşletmecisi).
}

Görüldüğü gibi işletme sahipleri ile yöneticileri tarafından, yerel halkın yaşam kalitesi ve turizm endüstrisinin gelişimi bakımından yavaş şehrin Seferihisar üzerindeki etkileri, hem olumlu hem de olumsuz yönlerden ele alınmaktadır. Bu tür araş- tırma sonuçları, yöre ile ilgili ileriye yönelik sağlıklı kararların alınmasında yardımcı olacak niteliktedir.

\section{Yavaş Şehir Olgusunun Seferihisar’a Sağladığı Katkı}

Yavaş şehir olgusunun uygulamaya konulmasıyla birlikte, genel olarak Seferihisar üzerinde ne gibi bir katkıda bulunduğunu alt başlıklar halinde şu şekilde özetlemek mümkündür: Yörenin tanıtımının yapilması, turizm hareketlerinin sadece yılın belirli dönemlerinde değil, yıl boyu görülmeye başlanması, düzenlenen sosyal etkinliklerin artması (konser, festival vb.), çevre düzenlemesine ve altyapıya önem verilmesi (yol, kaldırım ve evlerin bakımı; elektrik kabloların yer altına alınması vb.), yat limanı ve yeni işletmelerin açılması sonucunda istihdamın artması, halkın üretime teşvik edilmesi ve elde edilen gelirin artmasıyla birlikte ilçedeki yaşam kalitesinin artması. Bütün bu gelişmeler, yavaş şehir ölçütleri ile örtüşmektedir:

\begin{abstract}
Yavaş şehir olduktan sonra halk kabuğundan çıktı, sosyalleşti ve yaşama bakış açıları değişti. Daha önceden tutucu bir kasabaydı. Çevre düzenlemeleri yapıldı, bazıları güzel bazıları ise doğal yapıyı bozdu. Marinanın yapılması buradaki doğal yapıyı olumsuz etkiledi. Arkeolojik kazılar yapılmaya başlandı. Plajlara mavi bayrak alınmasına katkı sağladı (Katılımcı No: 4 - Kafe-bar Işletmecisi).
\end{abstract}

İkinci olarak, yavaş şehrin Seferihisar üzerinde genel anlamda olumsuz etkiye sahip olduğunun altını çizenlerin gerekçeleri incelendiğinde, artan arsa fiyatları ve düzenlenen sosyal etkinliklerin sayıca azlı̆̆ı görülmektedir. Yavaş şehir unvanına sahip olmakla birlikte ilçenin tanınırlığının artması, beraberinde aşırı kalabalık getirmiştir. Yavaş şehir olma ölçütleri arasında yöresel mimari özelliklerinin bulunmasına karşın, mimari ölçütlere uymayan yapılaşma da olumsuz görülen diğer nedenler arasındadır.

Yavaş şehir unvanının Seferihisar'a çok faydası olduğunu düşünmüyorum. Daha çok Sığacık ve Akarca'ya faydası oldu. Bu bölgelerde yazlık ve arsa satışı arttı. Sakin şehir herkese hitap eden bir yer değil, bu nedenle buraya çok şey kazandırmaz (Katılımo No: 1 - Otel $\dot{I}_{S ̧-}$ letmecisi).

Yavaş şehir olması burası için avantaj değil dezavantaj oluyor. Sosyal olanakların az olduğu bir yer. Burası huzur evi gibi olur (Katılımo No: 11 - İşletmeci).

Son olarak, yavaş şehir üyeliğinin elde edilmesi ve yerel seçim sonuçları arasında fazla bir zaman aralığı olmadığı için Seferihisar'da son yıllarda 
meydana gelen değişmenin yerel yönetimdeki değişimden mi kaynaklandığının, yoksa yavaş şehrin bir sonucu mu olduğunun anlaşılmasını güçleştirdiğini ifade eden aşağıdaki alıntının da önemine vurgu yapılması gereklidir. Belki de bu nedenle, bir süre daha beklemenin gerekliliği düşünülebilir.

\begin{abstract}
Seferihisar, çok durağan bir dönemde ve yerel yönetimin belirleneceği bir seçim sürecindeydi. Bu süreçte yerel yönetim değişti ve altı ay sonra yavaş şehir unva$\mathrm{n} 1$ alındı. Bu süreçten sonra ilçede değişim başladı. Bu değişim, yerel yönetimin çabası ile mi yoksa yavaş şehir unvanı ile birlikte mi oluştu bunu ayırt etmek zor. Bunu anlayabilmek için Türkiye'de yavaş şehir unvanını almış başka ilçelerdeki değişimleri gözlemlemek gerekiyor. Halkı bilinçlendirme çalışmaları, seminerler, kültürü koruma çalışmaları yavaş şehir unvanı ile birlikte yapıldı. Seferihisar, yavaş şehir unvanı ile birlikte gelişiyor olabilir ama yavaş şehir ölçütlerine uygun gelişiyor mu, bu tartışılır. Biz önce altyapı sonra gelişme olacağını düşünüyorduk fakat bu gelişme tam tersi oldu. Yavaş şehir unvanını Türkiye'de Seferihisar'dan çok daha fazla hak eden yerler var. Seferihisar, yavaş şehir özelliklerini sindiremedi, yavaş şehir biraz medyatik bir olay (Katılımoı No: 3 -Otel İşletmecisi).
\end{abstract}

Görüldüğü gibi yavaş şehrin turizm endüstrisi ve yerel halkın yaşam kalitesi açısından Seferihisar üzerinde etkileri konusunda, işletme sahipleri ve yöneticileri üç farklı düşünceye sahiptirler. Birinci grup, olumlu etkileri üzerinde dururken, ikinci grup olumsuz etkilerine vurgu yapmakta; üçüncü grup ise bu yönde yorum yapmanın güçlügü üzerinde durmaktadır.

\section{Belediye Başkanı ile Yapılan Görüşmenin Değerlendirilmesi}

Yavaş şehir düşüncesinin ortaya çıkışı, şimdiki uygulaması ve gelecekteki durumu ile ilgili olarak daha ayrıntılı bilgi almak amacıyla, 24 Eylül 2012 tarihinde Seferihisar Belediye Başkanı ile bir görüşme gerçekleştirildi. Yaklaşık 45 dakika süren görüşmede, kendisine toplam yedi adet soru yöneltildi ve görüşme sonuçları o anda kâğıt-kalem yöntemiyle not edildi. Bu görüşmeden elde edilen bulgular aşağıdaki şekilde özetlenebilir.

Belediye başkanı, yaşam kalitesi kavramı, aslında çok farklı ve kapsamlı bir konu olduğu halde bundan algılanan sonucun ekonomik gelişmişlik olduğunu dile getirirken konunun sadece ekonomik gelişmişlik düzeyine indirgenmesinin yanlış olduğunu yöre halkına anlatmaya çalıştıklarını ifade etmektedir. Burada verilmek istenen mesaj, ya- şamı kolay ve keyifli yaşayarak sürdürülebilirliğin sağlanması olduğu için, yavaş şehir olgusu, konunun anlaşılması ve anlatılması bakımından yardımcı olmaktadır.

Belediye başkanı, aslında kendilerinin hedefinin daha küçük çaplı bir turizm olduğunu dile getirmektedir. Seferihisar, kitle turizmi dışında ev pansiyonculuğunun ve günübirlik turizmin gelişmesine çok daha uygun bir yer olarak görünmektedir. O nedenle, çok fazla sayıda konut yapılması istenmemekte, turizmdeki kalitenin yükseltilmesi hedeflenmektedir. Gelecekte referans alınacak iki noktadan birincisi küçük ölçekli ve günübirlik turizmin geliştirilmesi; ikincisi ise kalitenin artt1rılmasıdır. Doğa ve kültür, korunmadığı ve yıp-

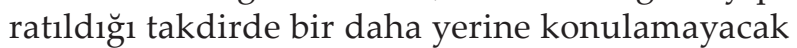
değerlerdir. Yöre halkının, zaman içinde bu durumu daha iyi anlaması ve Seferihisar'ın doğasına ve kültürüne sahip çıkması beklenmektedir. Organik olmayan tarım ürünleri ile organik tarım ürünlerinin piyasa fiyatları birbirinden farklıdır. Birbirine benzer, kalabalık, kentleşmiş turizm bölgeleri ile yavaş şehir unvanına sahip doğası korunmuş kültürel değerlerine sahip çıkan bir turizm bölgesinin de fiyatları birbirinden farklı olacaktır. Amaç, yavaş şehir olgusunun ortaya çıkaracağı imaj farkı ile Seferihisar'da bu farklılığı ortaya koyabilmektir.

Belediye başkanına göre, Seferihisar'da geleneklere, doğal, kültürel ve tarihi zenginliklere sahip çıkmanın değeri ve önemi yavaş şehir sayesinde daha iyi anlaşılmaktadır. En önemlisi, yöre halkı Seferihisarlı olmakla (bu unvana sahip olmakla) gurur duymaya başlamıştır. En fazla değişimin, yaşanan bu gururda olduğu ve kendisi ile gurur duyan bir kentli kimliğinin oluştuğu dile getirilmektedir. Halkın yaşam kalitesi ve gelir düzeyinde artış olduğunun altı da çizilmektedir. Bunun yanı sıra belediye başkanı, yavaş şehir olgusunun uluslararası alandaki logosu salyangoz olmasına karşın bu logonun Seferihisar'da yaşayan halkın ya da yöreyi ziyaret eden turistlerin gözünde olumsuz bir algı oluşturmadığını belirtmektedir. Aksine, yöre halkı ve dışarıdan gelen ziyaretçiler, salyangozun önünde resim çektirmektedir. En olumlu değişimler bile ilk başta tepki ile karşılanırken, Seferihisar halkı ve yönetiminin bunu başardığı düşünülmektedir. Seferihisar'ın yavaş şehir olduğunu duymayan kalmadığı gibi yavaş şehir olmaktan vazgeçilsin gibi bir önerinin gelmediği de vurgulanmaktadır. 


\section{SONUÇ VE ÖNERILER}

Yukarıdaki bölümlerde ayrıntılı şekilde ele alındığı üzere, yavaş şehir kavramı ve buna paralel olarak yavaş yemek ile turizm endüstrisi arasında da oldukça yakın bir ilişki söz konusudur. Bu ilişki daha çok, sürdürülebilir yaşam ve sürdürülebilir turizm ile ilgilidir. Turizm alanında bu iki kavram arasındaki ilişkiyi ele alan yeterli sayıda çalışmanın bulunmadığı varsayımından hareketle, bir çalışmanın yürütülmesi düşüncesi ortaya çıkmiştır. Buradan hareketle, yavaş şehir olgusunun, yerel halkın kentsel yaşam kalitesi üzerindeki etkisi araştırıldığında, artan turizm hareketliliği ile birlikte yerel halkın ekonomik anlamda kazanç sağlamaya başladığı ve bu nedenle halkın yavaş şehir uygulamasına sıcak baktığı görülmektedir. Kentsel yaşam kalitesi ile ilgili gözlemlenen olumlu eğilimler arasında, yeni istihdam alanlarının yaratılması, çevre düzenlemesi, doğal yaşamın korunması, planlı yapılaşma, sessizlik, mevcut gelenek-göreneklerinden oluşan kültürel değerlerin (yaşam biçimi, yeme-içe alışkanlığı, insanlar arası iletişim vb.) korunması, düzenlenen sosyal ve kültürel faaliyetlerde görülen artış sayılabilir.

Kentsel yaşam kalitesi açısından ele alınacak olumsuzluklar arasında ise diğer şehirlerden yaşanan göç ile birlikte yaşanan nüfus artışı ve kalabalığın beraberinde getirdiği gürültü ve trafik sorunu, yörenin değer kazanmaya başlamasıyla birlikte ortaya çıkan aşırı yapılaşma ve bunun beraberinde getirdiği arsa fiyatlarındaki artış, yaz dönemlerinde özellikle günübirlikçi sayısında gözlemlenen önemli artış, yaşam pahalılığı, günlük işleyişin bozulması ve yerel yönetimler tarafından sunulan hizmetlerde yaşanan sorunlar sayılabilir.

Seferihisar'da faaliyet gösteren işletmelerin sahip ya da yöneticileri ile yerel halk, yavaş şehir olgusunun yöre ekonomisi üzerinde olumlu yönde etkide bulunduğunun altını çizmektedirler. Bu gruba göre yavaş şehir, Seferihisar için önemli bir tanıtım kaynağ ya çıkan merak dürtüsü nedeniyle yöreye gelen ziyaretçi sayısında önemli bir artış ortaya çıkmıştır. Ev pansiyonculuğunun yanı sıra yeni otel işletmelerinin yapılması ile birlikte, özellikle yurtdışından yabancı turist gelmeye başladığı söylenmektedir. Seferihisar'ın yavaş şehir bakımından avantajlı olduğu ve kurallarının uygulanmaya devam edilmesi ile birlikte gelecekte daha çok turistin geleceği ve bunların otel dışına çıkmalarıyla yöre esnafının daha çok gelir elde edebileceği ifade edilmektedir.

Seferihisar'ın yavaş şehir olma şartlarını yeterince yerine getirmediği ve bu nedenle bazı doğal çevre üzerinde bazı sorunların ortaya çıktığı görülmektedir. Bir yandan yavaş şehir konusu gündeme getirilirken diğer taraftan yapılaşma ve gürültü kirliliğinin ve büyük ölçekli otel inşaat sayısının artması, bir çelişki olarak görülmektedir. Görüşme yapılan bazı kişiler, turizm endüstrisiyle ile ilgili olarak gelecek dönemlerde olumlu bir gelişme beklememekte; bunun nedenleri arasında ise yörenin turizm hareketliliği bakımından doyum noktasına yaklaşmasının önemli bir risk oluşturması gösterilmektedir. Bunun sonucunda da Seferihisar'ın Özdere, Çeşme ya da Kuşadası gibi yörelerde daha önceden görülen benzer sıkıntılara sahip olabileceği dile getirilmektedir.

Daha önceden kendi içine kapalı bir toplum olduğu dile getirilen Seferihisar halkı, sonrasında dışarıya açılma gereksinimi duymuştur. Bunun üzerinde, eğitim düzeyi daha yüksek kimselerin göç ederek ilçede yaşamaya başlamaları, gelen ziyaretçi sayısında nitel ve nicel artış ve yılda bir kez ücretsiz düzenlenmeye başlanan sinema günlerinin etkili olabileceği söylenebilir. Yerel halkın organik üretimde yer alması, ev pansiyonculuğunun gelişmesi, kadınların hediyelik eşya bağlamında üretime girmeleri, sonuçta halkın turizm bilincinin gelişmesine ve sahip olunan geleneksel değerlerin korunmasına neden olmaktadır. Bu durum ise yöre halkı tarafından olumlu bir gelişme olarak değerlendirilmektedir. Bunun yanı sıra gelişen her yörede gözlemlendiği gibi artan hareketlilik sonucunda, yerel halkın turizm endüstrisini gelir getiren bir kapı gibi görmeye başlamasıyla birlikte sahip olunan geleneksel yapının yerini ticarileşmenin alması, bunun sonucunda da sosyal dayanışmanın bozulması ve turist-halk ilişkilerinin daha çok ekonomik anlamda önem kazanması gibi tehlikelerin olabileceği de gözden uzak tutulmamalıdır. Bu konuda, hem kamu ve özel yöneticilerine hem de halka önemli sorumluluklar düşmektedir.

Son olarak, araştırmanın kısıtları arasında birkaç önemli konuyu belirtmek yeterli olacaktır. Birincisi, bu çalışma sadece İzmir'e bağlı bir ilçe olan Seferihisar şehrinde uygulamaya başlanan yavaş şehir örneğini incelemektedir. İkinci olarak, çalışmanın örneklemini Seferihisar'da yaşayan yerel halkın ya- 
nı sıra burada ticaret ile uğraşan bazı esnaf grubu oluşturmaktadır. Veri toplama aşaması nitel araştırma yöntemleri ile sınırlandırılmıştır. Dolayısıyla, araştırmadan elde edilen bulgular ışı̆̆ında, Türkiye ya da Dünya genelinde bir genelleme yapmak doğru olmayabilir. Bu nedenle, gelecek yillarda benzer bir konuda çalışma yapmak isteyen araştırmacıların, sonuçların benzerliğini test etmek için ulusal ya da uluslararası düzeyde farklı yavaş şehir örnekleriyle araştırma içeriğini zenginleştirmeleri, farklı gruplar arasında karşılaştırma yapabilmek için nicel araştırma yöntemlerinden yararlanmaları ve daha sağlıklı sonuçlara ulaşabilmek için katılımc1 gözlem gibi yöntemleri kullanmaları önerilmektedir.

\section{KAYNAKÇA}

Ap, J. (1992). Residents' Perceptions on Tourism Impacts, Annals of Tourism Research, 19(4): 665-690.

Arslan, Ş. ve Kutsal, Y.G. (1999). Geriatride Yaşam Kalitesinin Değerlendirilmesi, Geriatride Dergisi, 2 (3): 103-114.

Bilgi, M.G. (2103). Türkiye'nin Sakin Şehirlerinde Permakültürel Koruma, Planlama, Yönetim ve Eğitim Pratikleri, Selçuk Üniversitesi Sosyal Bilimler Enstitüsü Dergisi, 29: 45-59.

Bramwell, B. ve Sharman, A. (2006). Approachesto Sustainable Tourism Planning and Community Participation, İçinde Tourism and Sustainable Community Development, D. Hall ve G. Richards (Editörler), New York: Routledge.

Campbell, A., Converse, P.E., ve Rodgers, W.L. (1976). The Quality of American Life: Perceptions, Evaluations, and Satisfactions. New York: Russell Sage Foundation.

Cittaslow International, http://www.cittaslow.net/download/, Erişim tarihi: 5 Nisan 2012.

Cittaslow Türkiye, http://www.cittaslowturkiye.org/cittaslow-turkiye.html, Erişim tarihi: 21 Ekim 2013.

Çetin, T. (2009). Beypazarı'nda Turist-Yerel Halk Etkileşimi ve Turizmde Sosyal, Kültürel ve Ekonomik Etkileri, Türk Dünyası Incelemeleri Dergisi, 9 (1): 15-32.

Dogan, H.Z. (1989). Forms of Adjustment: Socio cultural Impacts of Tourism, Annals of Tourism Research,16 (2): 216-236.

Doğutürk, G. (2010). Mimari ve Yaşam Kalitesi Bağlamında Yavaş Şehir Hareketi ve Seferihisar Örneği, (Yayımlanmamış Yüksek Lisans Tezi), İstanbul: Mimar Sinan Güzel Sanatlar Üniversitesi Fen Bilimleri Enstitüsü.

Eceral, T. ve Özmen, C. A. (2009). Beypazarı'nda Turizm Gelişimi ve Yerel Ekonomik Kalkınma, Ekonomik ve Sosyal Araştırmalar Dergisi, 5 (2): 46-74.

Ekşioğlu, A.Y. (2011). Kentsel Yaşam Kalitesi ve İstanbul Örneği, (Yayımlanmamış Yüksek Lisans Tezi), İstanbul: Marmara Üniversitesi Sosyal Bilimler Enstitüsü.

Ergüven, M. H. (2011). Cittaslow-Yaşamaya Değer Şehirlerin Uluslararası Birliği: Vize Örneği, Organizasyon ve Yönetim Bilimleri Dergisi, 3c(2): 201-210.
Fletcher, J., Fyall, A., Gilbert, D. ve Wanhill, S. (2013). Tourism: Principlesand Practice. 5. Bask1, Londra: Pearson.

Fullagar, S., Wilson, E. ve Markwell, K. (2012). StartingcSlow: Thinking Through Slow Mobilities and Experiences, İçinde Slow Tourism: Experiences and Mobilities, S. Fullagar, E. Wilson ve K. Markwell (Editörler). Bristol: Channel View Publications.

Geray, C. (1998). Kentsel Yaşam Kalitesi ve Belediyeler, Türk İdare Dergisi, 421: 323-346.

Kabadayı, H. (2006). Yaşam Kalitesi ve Kullanıcı Memnuniyetinin Kentsel Tasarımdaki Etkisine Çok Boyutlu Yaklaşım (Yayımlanmamış Yüksek Lisans Tezi), İstanbul: İstanbul Teknik Üniversitesi Fen Bilimleri Enstitüsü.

Karabağ, O., Yücel, F.ve İnal, M. E. (2012) .Cittaslow Movement: An Opportunity for Branding Small Townsand Economic Development in Turkey, International Journal of EconomicResearch, 3c(3): 64-75.

Keskin, E.B. (2010) Sürdürülebilir Kent Kavramına Farklı Bir Bakış Olarak Yavaş Şehirler (Cittaslow): Seferihisar Örneği (Yayımlanmamış Yüksek Lisans Tezi), Kütahya: Dumlupınar Üniversitesi Sosyal Bilimler Enstitüsü.

Knox, P.L. (2005). Creating Ordinary Places: Slow Cities in a Fast World, Journal of Urban Design, 10 (1):1-11.

Koçak, H. (2008). Kentsel Yaşam Kalitesinin Geliştirilmesi İçin Stratejik Çalışma Alanları-I. Belediye Vizyonu. İstanbul: Okutan Yayıncilık.

Kozak, M. (2013). Giriş. İçinde Sürdürülebilir Turizm: KavramlarUygulamalar. M. Kozak (Editör), ss. 1-12. Ankara: Detay Yayıncilik.

Kozak, N., Kozak, M.A. ve Kozak, M. (2013). Genel Turizm: Ilkeler-Kavramlar, 13. Bask1. Ankara: Detay Yayıncılık.

Liu, J.cC. ve Var, T. (1986). Resident Attitudes Toward Tourism Impacts in Hawaii, Annals of TourismcResearch, $13 c(2): c 193-214$

Marans, R. (2007). Kentsel Yaşam Kalitesinin Ölçülmesi, Çev: Handan Dülger Türkoğlu, Mimarlık Dergisi, 335. http:// www.mimarlikdergisi.com, Erişim Tarihi: 14 Haziran 2013.

Mayer, H. ve Knox, P.L. (2006). Slow Cities: Sustainable Places in a Fast World, Journal of Urban Affairs, 28 (4): 321-334.

Mutdoğan, S. (2010). Seferihisar Örneğinde Sakin Şehir Hareketi / Understanding the Cittaslow Movement Through a Seferihisar - Case Study Gren Age Symposium, ss. 1-10. Mimar Sinan Güzel Sanatlar Üniversitesi, Mimarlık Fakültesi, 6-8 Aralık 2010, İstanbul.

Neal, J., Uysal, M. ve Sirgy, M. (2007). The Effect of Tourism Services on Travelers' Quality of life, Journal of Travel Research, 46: 154-163.

Öksüz, E. ve Malhan, S. (2005). Sağhı̆ga Bă̆lı Yaşam Kalitesi: Kalitemetri. Ankara: Başkent Üniversitesi.

Özdemir, S. (2012). Kırsal Kalkınmada Kırsal Turizmden Yararlanma Olanakları: Gökçeada Örneği, Karamanoğlu Mehmet Bey Üniversitesi Sosyal ve Ekonomik Araştırmalar Dergisi, 14 (23): 19-21.

Sapancalı, F. (2009). Toplumsal Açıdan Kentsel Yaşam Kalitesi. İzmir: Altın Nokta Basın Yayın. 
Szalai, A. (1980). The Meaning of Comparative Research on the Quality of Life. İçinde The Quality of Life, A. Szalai ve F. Andrews (Editörler) Beverly Hills, California: Sage.

Tağmat, T. S. (2007). Mimarlık ve Yaşam Kalitesi: Avrupa'da Kentsel Yaşam Kalitesi Yaklaşımları, Mimarlık Dergisi, 335, http://www.mimarlikdergisi.com, Erişim tarihi: 14 Haziran 2013

Türkiye İstatistik Kurumu Nüfus ve Vatandaşlık İşleri Genel Müdürlüğü Haber Bülteni (2013), Sayı: 13425, 20 Ocak.

Uslu, A. (2009). Sürdürülebilir Yeşil Kent Fikirleri, Örnekleri ve Türkiye İçin Dersler, 21. Uluslararası Yapı ve Yaşam Kongresi Bildiriler Kitabı, Bursa: TMMOB Mimarlar Odası Yayını.

Üçer, A.G. (2009). Kentsel Yaşam Kalitesinin Belediye Hizmetleri Kapsamında Belirlenmesine ve Geliştirilmesine Yönelik Bir Yaklaşım: Orta Ölçekli Kent Örnekleri (Yayımlanmamış Doktora Tezi), Ankara: Gazi Üniversitesi Fen Bilimleri Enstitüsü.
Veenhoven, R. (2000). The Four Qualities of Life, Ordering Conceptsand Measures of the Good Life, Journal of Happiness Studies, 1: 1-39.

Von Kamp, I., Leidelmeijer, K., Marsman, G. ve de Hollander, A. (2003). Urban Environmental Quality and Human Well-being towards a Conceptual Framework and Demarcation of Concepts; A Literature Study, Landscapeand Urban Planning, 6: 5-18.

Yıldız, H.T. (2007). Kentsel Yaşam Kalitesi: Kuram, Politika ve Uygulamalar, Mimarlık Dergisi, 335: 27. http://www.mimarlikdergisi.com, Erişim tarihi: 14 Haziran 2013.

Yurtseven, H. R. ve Kaya, O. (2011). Slow Tourists: A Comparative Research Based on Cittaslow Principles, American International Journal of Contemporary Research, 1 (2): 91-98.

Whittemore, R., Chase, S. K. ve Carol, L. M. (2001). Validity in Qualitative Research, Qualitative Health Research, 11 (4): 522-537. 